This item was submitted to Loughborough's Research Repository by the author.

Items in Figshare are protected by copyright, with all rights reserved, unless otherwise indicated.

\title{
Freedom within bars: maximum security prisoners' negotiations of identity through rap
}

PLEASE CITE THE PUBLISHED VERSION

http://dx.doi.org/10.1080/1070289X.2017.1287487

\section{PUBLISHER}

Routledge (@ Taylor \& Francis Group)

\section{VERSION}

AM (Accepted Manuscript)

\section{PUBLISHER STATEMENT}

This work is made available according to the conditions of the Creative Commons Attribution-NonCommercialNoDerivatives 4.0 International (CC BY-NC-ND 4.0) licence. Full details of this licence are available at: https://creativecommons.org/licenses/by-nc-nd/4.0/

\section{LICENCE}

CC BY-NC-ND 4.0

\section{REPOSITORY RECORD}

Bramwell, Richard. 2019. "Freedom Within Bars: Maximum Security Prisoners' Negotiations of Identity Through Rap”. figshare. https://hdl.handle.net/2134/23917. 


\section{Freedom within bars: maximum security prisoners' negotiations of identity through rap}

Richard Bramwell ${ }^{1}$

Department of Social Sciences, Loughborough University, Loughborough, United Kingdom

\section{Abstract:}

This paper examines the construction of prisoners' identity through rap in England's high security prisons. While hip hop studies has often addressed rap's connection to the social practices of criminalised youths, prison rap cultures have received scant attention. This paper draws on a series of rap workshops and interviews with prisoners to investigate the experiences of black prisoners in high security prisons and how identities are produced and negotiated through rap. Rap is associated with the production of a range of identities and identifications, enabling prisoners to accommodate themselves to the conditions of their incarceration and to challenge aspects of the criminal justice system that they experience as unfair or illegitimate.

Article History: Received 20 July 2015; Accepted 4 January 2017

Keywords: culture; England; hip hop; prison; racism; rap

\section{Introduction}

This paper examines the construction of prisoners' identities through rap in high security prisons in England. It draws on observations from three out of five of England's high security prisons, focussing on one in particular. The paper examines how identity and identification are produced through rap and the role that this cultural form plays in prison social life. As a black cultural form, rap provides a unique opportunity to address urgent issues surrounding equality and diversity within the Prison Service. Whereas black Britons make up roughly 3\% of the general population in the United Kingdom, black prisoners constitute approximately $15 \%$ of the prison population in England and Wales. In its 2008 report on equality in prisons the National Offender Management Service

\footnotetext{
${ }^{1}$ Richard Bramwell r.bramwell@lboro.ac.uk
} 
acknowledged that 'there is greater disproportionality in the number of Black people in prisons in the UK than there is in the United States' (NOMS 2008).

As this paper will focus on rap performances in England, it is important to explain our use of the terms rap and hip hop, particularly as they are often conflated. I use the term rap to refer to the practice of lyrical performance, by an $\mathrm{MC}$ or rapper, often over an instrumental background (Bennet 1999). Rap is a prominent feature in hip hop and other musical genres, including garage, jungle and grime. Hip hop was developed in the South Bronx (Rose 1994; Chang 2005), and has since become one of the biggest selling popular music genres in the world. By focussing my analysis around rap, I wish to cut across musical genre and foreground the importance of this linguistic practice in identity formation and prison social life.

Hip hop studies has continually addressed the issue of rap's connection to the social practices of marginalised and criminalised youths (Cummings 2012). Russell Potter (1995) compares the experiences of African Americans to those of colonised peoples, and Tricia Rose (1994) discusses how, in the context of the so-called war on drugs, rap music provided black urban youths in the USA with the cultural resources to challenge police brutality and legalised injustice. Furthermore, Eithne Quinn's analysis of gangsta rap identifies the emergence of this genre as a response to the 'calculated offensive' launched by Reagan and Bush 'against some of the most vulnerable and beleaguered communities in America' (Quinn 2005). However, while she highlights connections between 'surging imprisonment rates', 'correction-driven policies ... [which] locked out many young black men from lawful employment' and the development of a 'penitentiary culture' in the vulnerable communities from which this rap genre emerged, Quinn's (2005) incisive analysis of the development of gangsta rap moves outwards, from the penitentiary, towards 'the carceral city'. Given the attention paid to the relationship between hip hop and marginalised and criminalised youths, it is striking that rap culture in prisons has been overlooked by scholars. Cusick (2008) examines the use of music, including hip hop, as a method of torture in American detention centres during the so-called 'war on terror', however her study does not address prisoner rap culture 
per se. Although Pardue (2004) offers perhaps the only research on the production of rap by prisoners in his study of hip hop as a form of arts-based education in Brazilian youth correctional facilities, there are no studies of rap culture in prisons in either the United States or the United Kingdom.

High security prisons in England have significantly changed over the last twenty years. In one of the five high security dispersal prisons, ${ }^{i}$ the black and minority ethnic prisoner population has increased from $21 \%$ to over $60 \%$ (with black prisoners making up over $30 \%$ of the total population). In a further two of these prisons, black and mixed 'race' prisoners constitute approximately $20 \%$ of the population. Liebling and Arnold (2012) state that in these prisons "“street life" (and language) [is now] more prominent in shaping prisoner values, behaviour and attitudes'. While their reference to black vernacular culture through the term 'street life' is open to critique for its reductiveness (as is the term's use as a proxy for black culture in criminological studies more broadly cf. Anderson 1999; Ilan 2012) Liebling and Arnold (2012) register a shift in power relations within the prisoner subculture. In particular, they identify displacement of 'white professional gangsters' from their dominant position in the prisoner hierarchy by black prisoners. It is worth noting that their opposition of 'professional' gangsters to those who embody 'street' cultural practices, draws on a moral economy peculiar to the context of the prison. Through interviews and conversations with prisoners and prison staff, as well as a series of rap workshops led by the author with a group of prisoners, this article explores how men - principally black men negotiate their identities in high security prisons. With increasing numbers of black prisoners, black British popular culture is playing a greater role in the social life within high security prisons. It is striking that are no detailed qualitative studies of black culture within British prisons and I argue that such research is imperative if the causes and effects of the over-representation of black men within prison populations are to be adequately addressed. 


\section{Exploring 'race' in English prisons through rap}

This paper on rap culture in English prisons is based on fieldwork conducted as part of two research projects on the construction of identity in prisons. A rap workshop was piloted during the first project, which was based in the Institute of Criminology, University of Cambridge, and focused on high security prisons in northern England. That pilot was followed up in a study, based in the Department of Social Sciences, Loughborough University, on the performance and circulation of rap culture in penal and social institutions. The research projects were conducted by multidisciplinary teams and the fieldwork was carried out at three prisons. The first, HMP Coldfield, is located over 200 miles from London, from where a substantial proportion of its black prisoners came, and has a prisoner population of approximately 600. The second, HMP Wharton, is in northern England, and has a population of around 800. The third, HMP Marshwood, is in southern England and has a population of around 450. I have used pseudonyms for the prisons and prisoners in order to maintain the anonymity of the research participants.

The three prisons held significantly different proportions of ethnic minority prisoners. Approximately $62 \%$ of the prisoner population at Coldfield was white British, with $14 \%$ black and $3 \%$ mixed 'race'. By contrast $78 \%$ of the population of Wharton prison was white British, with black prisoners composing $9 \%$ of the population and mixed 'race' prisoners constituting $3 \%$ of the population. In Marshwood, the white British population was approximately 38\%, with black prisoners constituting $33 \%$ and mixed 'race' prisoners composing $4 \%$ of the population. The black population in the high security prison group is slightly higher than the national average, at $16 \%$. All of the prisons held adult males serving sentences of four years and over. Those attending the rap workshops in Coldfield were serving sentences of between 15 and 33 years.

The fieldwork at Coldfield commenced with a two-month period of observation. This was followed by interviews with prisoners, prison officers and members of the senior management team over a period of three months. Through informal conversations with prisoners during the observation period I learned that the prison's engagement with black prisoners and their cultural interests was limited. I began to organise a workshop in conjunction with a group of prisoners who 
were interested in rap, with the agreement of the prison's Governor and the support of other members of the senior management team. This workshop ran during the interview phase of the fieldwork. In contrast to Coldfield, Wharton and Marshwood provided prisoners with access to a variety of artistic development activities, including creative writing classes and music production courses. A number of prisoners with interests in writing rap lyrics were enrolled on the music production courses. Several of these prisoners participated in interviews. More than 110 prisoners were interviewed across the three sites. Approximately 45 per cent of these interviewees were black or mixed race, and 20 per cent were Asian. Roughly 30 per cent were white. Almost half of the sample described themselves, or were described by the prison, as Muslim. A quarter of the sample were Christian, about a tenth were atheist, and a handful were Buddhist or Rastafarian.

In the three prisons in which fieldwork was conducted the majority of black prisoners were also Muslim, many of whom had converted while in prison. In their investigation of how new ethnicities are produced within the prison environment, Rod Earle and Coretta Phillips (2013) argue that Muslims now occupy a similar position to that of blacks in the 1980s. Spalek and El Hassan (2006) highlight that the high percentage of Muslim prisoners in England and Wales that are from black ethnic backgrounds (34.08\%), in comparison with the percentage of Muslims in the general population that are black $(6.88 \%)$, suggests that 'in prison conversion accounts for some of the large numbers of Black Muslim prisoners.' In his foreword to the National Offenders Management Service's 'Race Review', the then Director General of the service, Phil Wheatley stated that getting 'race' right was an integral part of managing prisons: 'Getting race wrong is dangerous to society, duplicates resources and wastes time and money. It also sours relations between prisoners and staff - the key component in securing control, order, and a reduction in re-offending.' (NOMS 2008). I suggest that by attending to practices - such as rap - through which prisoners construct their identities and express their identifications and dis-identifications, scholars and prison service managers will better understand the experiences of black British prisoners. In the context of increasing social and cultural distance between staff and prisoners, where 'ethnicity [can be] a 
"barrier to trust"” (Liebling, A., Arnold, H., \& Straub, C. 2012), the rap workshop provided a means through which to engage with prisoners who were considered difficult to reach by prison staff. I argue that rap provides a portal through which to engage with these prisoners on their own terms. Through this approach I aim to highlight the various, often complex, ways in which black British and black British Muslim prisoners draw on rap culture in the construction of their identities.

Senior prison service managers have acknowledged that institutional racism exists within prisons (Narey 2001; Bennet 2013). In their study of race relations in English prisons Genders and Player (1989) suggested that 'racial discrimination is intrinsic to the social organization of prisons':

In addition to being the product of a few racially prejudiced individuals, it is also the consequence of a complex interaction of racial stereotyping and the attempts by prison staff to achieve the multifarious and sometimes conflicting goals of the institution.

Daniéle Joly's work on race relations in prison highlights the impact of overt racism on the character of the prison service. She uses the example of a legal action brought by John Alexander who 'had been unlawfully discriminated against by the Home Office in October/November 1983' (Joly 2007) to examine how written reports produced by prison staff provided clear evidence of racial discrimination. In response to this case the prison service began to take measures to eliminate discrimination, including directions that racist remarks be avoided in written reports on inmates. Institutional racism returned as a significant issue for the prison service following the murder of Zaid Mubarek in Feltham in 2000. Martin Narey, Director General of the Prison Service, accepted that in addition to the malicious racism that existed in prisons, the Prison Service was also institutionally racist (Narey 2001). Phillips (2012) argues that while 'it is the unfair treatment of minority ethnic prisons [sic] by largely white prison officers which has plagued the prison service for more than three decades' there have been substantial improvements in the relations between prison officers and prisoners. Nevertheless, Phillips' study of the 'multicultural prison' highlights various ways in which informal discrimination and covert racism continue to shape prisoners' experiences and undermine the legitimacy of the criminal justice system. 
In Coldfield black prisoners frequently complained about negative entries being made in their prison records (about 'aggressive' behaviour) in response to their use of physical gestures ('talking with [our] hands') when communicating with officers; their underemployment in key areas of the prison; and the lack of support for their 'progression' (i.e. downgrading of their security category and chances of getting out of the high security estate). Some of these concerns were supported by Coldfield's equality monitoring data and their records of downgrading prisoners. Black prisoners were underemployed in the kitchens and on residential units. Furthermore, during the year, from February 2013 to January 2014, only six prisoners had their category A security status downgraded by that prison. All were white British.

The themes of racism, unequal treatment within the penal system, and the expression of black and black Muslim identities were employed in a number of songs performed in the rap workshop at Coldfield. In Wharton and Marshwood prisoners talked about how the music production classes provided the opportunity for them to gain a sense of freedom, 'when I put the headphones on I'm just in another world, I'm not in prison', and equipped them with skills that orient them towards life beyond their imprisonment. Some of the research participants' comments about the workshop in Coldfield corresponded with music therapists' accounts of the impact of their work. Tuastad and O'Grady (2013) state that participants in their studies, inside and outside of prisons, 'describe music therapy as important for their rehabilitation process and also for improving their quality of life.' Similarly, Daveson and Edwards (2001) identify how lyric writing and performance can assist in the reduction of stress and frustration for prisoners: 'Song writing ... allowed for self-expression. ... Singing ... and listening to songs being sung were identified by participants as assisting in the reduction of stress and the levels of anger and frustration.' I argue that in addition to providing resources through which prisoners may accommodate themselves to their conditions of confinement, rap is also mobilised by prisoners to challenge aspects of those conditions that they consider to be unfair, illegitimate, or discriminatory. Some of the raps performed during the workshop expressed opposition to the prison. Prisoners moved about the 
space freely, gesturing with their hands as they communicated with their audience. These forms of expression did not simply facilitate the adjustment of prisoners to their conditions. Through this cultural practice, prisoners in the group challenged the legitimacy of some of the institutional practices to which they were subject. These rap performances highlight the connections between power and resistance in the construction of identity. Prisoners symbolically challenged aspects of their experience and in some cases projected healthy identities in a culturally meaningful way.

\section{Coldfield rap workshop}

The rap workshops that I led began on the 6th of February 2014 and continued each Thursday morning until the 3rd of April 2014. Each session was three hours long and took place in the education area of the prison. Four members of the workshop were selected from prisoners that I had met during the course of my observations on the prison's residential wings, who were interested in rap. An additional three participants were selected on the basis of recommendations from these prisoners of others that they knew were interested in rap. All of these prisoners were from the main (generally non sex-offender) wings. Due to security restrictions limiting the mixing of 'main' and 'vulnerable' prisoners (largely sex-offenders), the workshop could include only main wing prisoners. Consequently two prisoners that I had met on vulnerable prisoner wings, who were able rappers, were not invited to participate. The first workshop began with readings of the works of the dub poet Linton Kwesi Johnson, followed by close analysis of 'Inglan is a Bitch' and 'Sonny's Lettah', and concluded with discussions of Johnson's essay 'Jamaican Rebel Music' and contemporary black British culture. The sessions developed through oral performances, analysis of rap lyrics and music videos, discussions of prisoners' own rap songs, and of scholarly work on black vernacular culture. Gradually the workshop sessions led to more self-directed activities, with prisoners organising freestyle performances and rapping in the round. Music and music videos were brought into the prison on a digital dictaphone and played back on the audio visual equipment in the education area of the prison. Following the introductory session the prisoners requested that I brought in instrumentals in order to facilitate their rapping. These were downloaded from a free 
mixtape website, brought into the prison on the dictaphone, and then transferred to the prison's education computers. The men attending the group were all black. This included Caribbean, BritishCaribbean, and British-African. The group consisted of seven prisoners, including one Rastafarian and six Muslims.

Early lyrics sung by the men indicated the significance of rap to the existing prisoner subculture. In the lyrics below Patrick draws on views of sex-offenders that I found widespread amongst both prison officers and prisoners on the main wings at Coldfield.

Bwoy yuh fi quit yay an stop move like Garry Glitter

Hollow point [bullets] will mek yuh [bone] morrow litta'

Go look fi mamacita stop play wide di little pickney [children's] clitta The injunctions against paedophilia and the legitimation of violence against sex-offenders can be seen as part of the wider prisoner subculture, that is taken up in this black cultural form. Through these lyrics the rapper constructs a masculinity, which is opposed to the 'strange' masculine form invoked through the figure of 'Gary Glitter'. Rather than prematurely suggest that these lyrics provide evidence of the association of particular genres of rap with forms of hyper-masculinity (Jamison 2006), I want to highlight that there is no association of rap with anti-paedophile rhetoric in either scholarly or mainstream debates on rap culture. Alex Perullo, in his study of Tanzanian hip hop, highlights the need to examine rap lyrics in context. Perullo (2005) argues that the repetition of particular songs by Tanzanian youth occurs ‘when a song reflects common concerns.' In Perullo’s case it is the national political context that is most relevant to the 'strong message' rap songs that he examines. In the present study the institutional context of the prison is, in some cases, more relevant that the wider socio-political context.

In their work on 'race', gender and sexuality, Bosworth and Carrabine argue that gendered identities are reinforced through the routine operation of prisons. One of the ways these are reinforced is through the separation of prisoners into 'main' and 'vulnerable' wings. During the present study I observed both prison officers and (main wing) prisoners discuss sex-offenders in disparaging terms. In one incident a prison officer described to his colleagues how he would 'bait', 
or wind up, a particular main wing prisoner on that prisoner's way to the visiting area, by suggesting that he was from another wing designated for vulnerable prisoners (thereby associating this man with sex offenders). In this manner some officers and prisoners represented sex-offenders as embodying a repugnant form of masculinity. In another case, a 'main wing' prisoner (who could be described as a white 'professional' gangster) expressed concern, during the course of an interview, about paedophiles seeing his young child during visits (one of the only occasions on which 'main' and 'vulnerable' prisoners shared the same space). I suggest that the proximity of significant numbers of 'vulnerable prisoners' and Patrick's censure of 'strange' masculine forms, highlights how rap adapts to particular contexts. In contrast to Liebling and Arnold, who draw on importation theories in prison sociology in their characterisation of the role of 'street' life and language in Whitemoor, I suggest that prison rap lyrics offer a portal through which to examine the importation and adaptation of black vernacular culture to the moral economy of the English penal system.

Patrick also employed a chorus in some of his early performances, which prompted responses from members of the group, who sang this chorus along with him. The chorus represents the rapper as a defiant figure, resistant to the authority of the prison: 'Nuttin' can't make me change, Nuttin' can't make me rearrange/ Nuttin' can't make me act strange'. The familiarity demonstrated by the other prisoners with these lyrics and their participation in this prisoner's performance foreground the role that rap plays in the organisation of Coldfield's prisoner subculture. This rap was a recurring feature in the early workshop sessions. The participation by workshop members in the performance of this chorus highlights the role of antiphony in the construction of identity in rap cultures. Gilroy (1991) argues that music 'and its rituals can be used to create a model whereby identity can be understood as something other than a fixed essence or a vague and utterly contingent construction':

Black identity ... is lived as a coherent (if not always stable) experiential sense of self. Though this identity is often felt to be natural and spontaneous, it remains the outcome of practical activity: language, gesture, bodily significations, desires. (Gilroy 1991) 
In the context of the Coldfield workshop, the rapper solicited identity from his audience through his rapping, and that audience in turn produced identification in response to his performance: nodding their heads, moving their bodies, and singing along during the chorus. In consideration of the work undertaken in the antiphonal exchange between the rapper and audience, it is worth noting that the MCs position was constructed through the combination of linguistic skills with themes and values that were circulated within the pre-existing prison subculture. The adoption of anti sex-offender values through this cultural form, served to distance this group of prisoners from a prison regime that they experienced as unfair and discriminatory through the mobilisation of a racialised biopolitics (Gilroy 1994). A black cultural identity was constructed through the opposition of a racialised and othered sexuality (conjured through the figure of the white rocker Gary Glitter) to a normative masculinity, which was embodied by the rapper and affirmed by his audience.

As the workshops continued the range of interests expressed in prisoners' lyrics broadened. These included representations of urban dwelling, projections of future selves, criticisms of the prison and an impromptu performance of romantic devotion. In 'Graffiti Scripturez' James produced a representation of urban dwelling, which highlights the pressures of urban poverty and violence. The lyrics also foreground the role of rap in providing a source of pride, a means through which to reflect on issues of social inequality and to produce catharsis.

Ready and able, label me the British saviour of rap I'm from the gritty side of London, fools get slapped and clapped.

As well as ballas and macs by borderline psychopaths

Struggles in the ghettos, drugs sell, so do the maths.

Temperatures raising sign of the times there's no disguise

Thirty year recs aint the shit I recognise.

So I, fall back you got this man on a mission

I walk in the shadows and gauge the competition

Sit and listen then perfect my composition

I'm in the premiership I leave you in the lower division.

The cost of living's dear, paradoxically life's cheap

Laying in my bed, so much pressure I can't sleep. 
I grit my teeth, draw for my pad and unsheathe my pen

Contemplate while scrawling the world's end.

James, who has been sentenced to life imprisonment and to serve a minimum of 25 years before he is eligible for parole, stated that the aim of this song was not to glorify violence but simply to reflect on the world as he had experienced it. Tia DeNora (1999) argues that 'music is a cultural resource that actors may mobilize for their on-going work of self-construction and the emotional, memory and biographical work such a project entails'. The depictions of social malaise combined with reflections on the existential angst produced by the experience of imprisonment on a very long sentence highlight how this cultural form provides prisoners with the resources to reflexively fashion their identities. It is also worth noting the use of creative licence in the reference to 'Thirty year recs', by a prisoner serving a recommended minimum of 25 years, to convey the difficulty of coming to terms with a long sentence. Rather than solely documenting experience, the construction of this rap combined considerations of how the words fit with the beat as well as how the lyrics might be interpreted by an audience. This is a reminder that rap cannot be assumed to be a form of sincere and literal testimony as, like other art forms, it carries fictive qualities and makes use of literary, musical and performative devices in the pursuit of aesthetic value (c.f. Kubrin and Nielson 2014 on the use of rap lyrics as evidence of defendants' guilt in criminal proceedings in the USA). In contrast to James's realist representation of urban life, Clive's 'Hold Me Back' presents the rapper as wanting to escape the entanglements with his past criminal life and projects an image of a changed future self:

Try fe hold me back, but forward I keep pushing

Hold me back, bad man and police always looking.

Me nuh go back to the way of the past, cause I never like how I was living

And I done been down that road long time and I just grave yard of the prison.

It is significant that this projection of a changed future self maintains a resistance to authority. Clive presents the cause of his break with the past as his own will, which is now asserted in opposition to criminal elements in society and criminal justice agencies. By distinguishing himself and his goals from both 'bad man' and 'police' he offers to his audience a representation of a self reformed on its 
own terms, not those of the criminal justice system. The contrasting positions constructed through Patrick, James and Clive's lyrics draws attention to the varying responses of these men to their conditions of incarceration. Throughout the workshop, lyrical references were made to the fast pace of urban life, humiliating experiences within the prison, representations of the prison's illegitimacy, experiences of racism, the challenges of maintaining subjective integrity, and affirmations of black collective identities.

In his study of young people's use of hip hop cultural 'texts', Greg Dimitriadis (2001) argues for the necessity of attending to the 'concrete contexts production and consumption' in the analysis of performative processes. Following his description of a shift within hip hop from live performance in its original sites of performance, towards a commodified, mass mediated form, Dimitriadis focuses his analysis on young people's uses and interpretations of hip hop 'texts'. Through a combination of interviews and informal observation Dimitriadis shows how young people use these 'texts' to index their social relationships and construct a sense of place. While it is certainly the case that globalised networks of commodity production and distribution have played a significant role in the expansion of hip hop culture, I argue that the rapping in the workshop at Coldfield demonstrates the continued importance of performance in rap cultures. I suggest that Dimitriadis's description of a shift from live performance towards mediated text in hip hop culture is too absolute. Given that even prior to the consolidation of hip hop as a relatively coherent cultural form, the interplay between recorded music and live performance was a distinctive feature of black Atlantic cultures (Gilroy 1993). However, I want to build upon Dimitriadis's call for greater attentiveness to the significance of the contexts of consumption and production in studies of rap. I argue that the institutional context plays an important role in the shaping of performances and the social relations activated in those events. Rap performances take on a different character in nightclubs (Bramwell 2015), record shops (Bennet 1999), and community centres (Dimitriadis 2001). Rap performances in English prisons invoke distinct values (anti sex-offender views) and terminology ('recs' to refer to the tariff recommended by a judge) while at the same time drawing 
on generic conventions, rhetorical strategies and cultural references also employed in mainstream rap cultures. Through this combination of institutional and broader cultural references, these rappers give shape and meaning to their experiences of incarceration.

The opposition expressed to the criminal justice system in some of these lyrics is associated with this prison's lack of engagement with black prisoners and black culture. Following a presentation of this research to the governors of England's high security prisons, I was invited by the incoming governor of Coldfield to work with members of his senior management team to improve relations with the prison's black population. Amongst other activities, members of the research team planned and contributed to the first black history month ran by the prison in six years. This senior prison service manager, acknowledged that there had been weak 'management attention' in the area of equality and diversity and identified the need for the prison to 'promote constructive engagement with the BME and Muslim community'. I argue that further engagement by prison service managers and staff with prisoners' experiences and cultural practices is necessary to tackle the systematic discrimination that has beset the service for over thirty years.

In Earle and Philips's study of identity, ethnicity and social relations in two English prisons, they draw on Stuart Hall's formulation of new ethnicities, in order to analyse how persistent patterns of racism are reproduced and challenged in the prison system. Drawing on interviews with prisoners they identify how, in the contemporary social context, Muslims now occupy the position of the irredeemable Other 'just as Black prisoners with "chips on their shoulders" and aggressive antiauthority stances were in the prisons of the 1980s' (Earle and Phillips 2013). Earle and Philips criticise the prison service's attempt to manage equality and diversity through equality monitoring data, which they argue 'can appear to force an image out of a person that is always more aligned with its own conflicting goals ... than it is with the person's sense of themselves.' The rap songs written and performed in the Coldfield workshop provide a portal through which to understand the experiences of the prison's black population on their own terms. However, it is important to note that in his formulation of the 'New Ethnicities' paradigm, Hall (1992) argued that 'issues of race 
always appear historically in articulation, in a formation, with other categories and divisions and are constantly crossed and recrossed by the categories of class, of gender and ethnicity.' Coldfield's black prisoners also negotiate their position in relation to other groups, such as 'white professional gangsters', terrorists, and sex-offenders.

While the workshop performances certainly highlight opposition to a prison regime that black prisoners felt to be unjust, some of these performances also foreground what bell hooks (1992) describes as the 'life threatening choke hold patriarchal masculinity imposes on black men.' The adoption and collective affirmation of anti sex-offender values within prison rap culture reveal how this choke hold is intensified within the moral economy of the penal system. This restrictive construction of masculinity is coupled in the raps produced in the workshop with an individualisation of experience and rejection of society and social institutions. The limited terms through which notions of individual progress are represented in these raps is indicative of the stagnation and alienation experienced by these prisoners in Coldfield and the dismal prospects for their rehabilitation and eventual reintegration into society.

\section{Negotiating black Muslim identities through rap}

Following the discussion of how black prisoners express themselves through rap, I now wish to turn my attention towards a consideration of the multiple and sometimes ambivalent positions taken by black Muslim prisoners in relation to rap culture. Prisoners in the rap workshop did not solely construct their identities in opposition to the prison. They drew on a range of social, cultural and religious references in their lyrics. In Ashley's 'Real Talk' he raps, 'I thought my destiny was to have my kids next to me/ And be up in the charts but Allah keeps testing me/ Putting me through dramas to try to see the best in me'. The construction of black British Muslim identities through rap was a significant feature in many of the lyrics produced in the workshop. Joly and Beckford (2006) argue that racial and religious identities have converged in British prisons, and Earle and Philips (2013) contend that Muslim prisoners now occupy a similar structural position to black prisoners in the 1980s. I argue that rap provides a valuable portal through which to engage with the negotiation 
of black British Muslim identities in prisoner subcultures. Black Muslim prisoners in Coldfield, Wharton and Marshwood adopted a range of positions through rap and in relation to rap. While those in the workshop maintained a relation to music, some felt that this ongoing relationship conflicted with their Muslim identities.

The relationship between music and Islam is complex and varies greatly across different historical and cultural contexts (Shiloah 2001). However, there are pervasive debates around whether or not music is prohibited within Islam, or haram (Marcus 2007). When considering how his religious practice related to his continuing use of music Ashley, who had participated in London's rap scene before his current sentence, stated:

One, I was Muslim outside, and two, it [rap music] was something that I done to a high level. So it's hard to get it out of me. Like I'm not perfect, and I'm far from perfect, but if there's things that I have to work on that would be one, but that would be my hardest one. I prefer to stop smoking, I prefer to stop swearing. I would prefer to do a lot... I would prefer to stop a lot of things that I shouldn't do, and leave that one until last, because it's such a big passion.

It is worth noting that while Ashley felt that his rapping compromised his religious commitment, he considered it to be a passion through which he could also express his devotion to Allah. Some workshop participants (who did not find any tension between being a Muslim and being a rapper) nevertheless found their practices challenged by other prisoners who viewed music as prohibited within Islam. Clive highlighted how being able to rap in the education area was preferable to rapping in his cell on the wing:

You've got next door, their area, you get me? Someone's like, 'Oh, but that's wrong, you're not supposed to do that' and I said, 'Fuck off, man! ... No one here is perfect, and don't tell me how to live my life, I'm doing what I do, and when I do', you get me? But, like I said ... it's better to do that there than on the wing. The negotiation of black British Muslim identities in prison takes place both through deeply subjective relations with music and religious practice as well as through inter-subjective relations with other prisoners.

The different positions adopted by workshop participants through their ongoing relation to rap, contrasted with black Muslim prisoners whose relation to Islam had led them to distance themselves from music. Paul, who briefly attended part of the first workshop before deciding to 
leave, stated that he could not be involved in the sessions because of prohibitions within Islam against music. There were some similarities between Paul's distancing of himself from music and the positions adopted by some prisoners at Wharton and Marchwood. Matthew forcefully rejected rap music which he saw as incompatible with Islam:

Basically because now that I am a Muslim and I know that it is prohibited ... I know that it is not good for me. ... Since becoming Muslim, any time I look back on certain tracks, I can always see something in there where it is propagating badness, whether it be something simple, like back then talking about boyfriend and girlfriend that's normal. Hearing that music is totally normal, but becoming a Muslim now, I just hear fornication. I hear about er - selling drugs and making money. Even in - let's say they don't talk about selling drugs, they are just talking about selling music and then making money. To me it is very very shallow, like talking about money and aspiring to obtain worldly things, is incredibly shallow to me now. So I don't get that same buzz and enjoyment that I used to. So yeah, not only is it prohibited, but it doesn't do it for me in that way.

Although Matthew had previously performed rap music on pirate radio prior to his conversion to Islam, he maintained an opposition to music even while he recognised the work of Muslim rappers, such as Common and Mos Def, could be directed to a greater good: 'whilst they might speak some goodness, they are going through a means that is harming their own self.' Despite recalling his admiration for lyrical word play in rap and still valuing the poetic aspects of this art form, Matthew insisted that music was incompatible with Islam: 'it is not just rap, it could be classical music.' Indeed the sacrifice that he made in so complete a rejection of music was presented as an indicator of his commitment:

There's some people who, because they were never really involved in music, they don't really... they have no feelings of it either way, giving up music was easy for them, because they had no real affiliation. With me because I was into music quite a lot, obviously perhaps for me it was a greater test for me than maybe a Muslim who grew up in a Muslim, an Islamic environment. ... Maybe my reward will be greater because of the fact that I know that I did use to like music.

Black British Muslim prisoners adopt a range of positions through rap performances, listening to rap music, and abstaining from rap. The contrasting positions constructed through rap and in relation to rap, draws attention to the significance of this cultural form in the construction of contemporary British identities. 
In his work on 'Gospel rap' Dehanas (2013) argues that hip hop performance endows rappers' religious beliefs with an 'embodied authenticity', grounding and amplifying their faith through bodily performance. While the embodied nature of rap certainly plays a powerful role in the realisation of identities, it is clear that in prisoner subcultures identities are constructed both through and against rap, often in complex ways. The negotiation of black British Muslim identities through and in relation to this cultural form highlights the complexity of the identity work undertaken through rap. Ian, a mixed 'race' Muslim prisoner at HMP Wharton, still maintained a relationship with rap music, which he said connected him to the person he was before his imprisonment and enabled him to reflect on his development: 'the distance between then and now, so it actually takes my mind on a bigger journey than just the music itself, because then it makes me think about the transition and how much has changed.' As in Clive's case Ian's ongoing relationship with music acknowledged other Muslims' views that music was prohibited. Importantly his relationship with music had become private. However, Ian adopted a more critical perspective towards prohibitions against music:

A lot of the things which I may do, like music, for example ... I would probably do it in the confines of my own cell in my space, but not around other people. Because it's not looked upon as correct and appropriate, in terms of what it represents. Some people who are Muslim don't understand why it is that music is said to be haram, they just, they hear someone, a scholar or somebody say it's haram and they think I can't have anything to do with it. ... And so some people get a bit - they think too black and white, and they decide that something either is prohibited or it's not prohibited, when sometimes it's not that simple.

The variety of positions constructed through rap by Muslim prisoners highlight how norms and values within prison rap cultures are negotiated by prisoners. Although Ian accommodated himself to the dominant perspective amongst Muslims within the prison, in his view his ongoing relation to rap music did not compromise his religious commitment. In contrast to the 'ideal communicative situation' described by Gilroy (1991), Ian's ongoing project of identity construction took place through listening to recorded performances in private and organising these 'texts' in relation to a biographical 'journey'. Set alongside the perspectives of other prisoners (amongst whom some were engaged in the production of a British Muslim rap culture) Ian's relation to rap highlights the 
complex role that this cultural form plays in the development of black British Muslim identities in prisons.

\section{Conclusion}

This paper has sought to contribute to prison sociology and hip hop studies by examining the construction of identity through rap in prisons. In England's high security prisons, rap provides prisoners with the cultural resources through which to pronounce upon their experiences within the criminal justice system and to come to terms with the demands of serving long prison sentences. The distance between (largely white) prison staff and black prisoners, has raised concerns amongst black prisoners about their unfavourable treatment in comparison to white prisoners, and resulted in poorer outcomes for blacks in English prisons. Through a greater understanding of the complex role that rap plays in high security prisons, it may be possible to work towards incorporating the culture of black Britons within the regime of the 'multicultural prison' and to begin to bridge the distance between prison officers and this over-represented group.

In addition to providing a vantage point on the experiences of black prisoners in general, rap offers an invaluable lens through which to investigate the complexity of black Muslim identities in British prisons. Understood as a black cultural form, as well as a potential source of ambivalence and dis-identification in the context of particular strands of Islamic belief, rap helps shine a light on the negotiation of black and Muslim prisoner identities.

Rap provides resources through which prisoners construct their identities through music, speech, gesture and bodily signification. This cultural form plays a complex role in prisoner subcultures and demonstrates that cultural practices are not simply imported from the outside world into prisons. Pre-existing values within the prison subculture, such as moralistic and punitive attitudes to sex offenders, may be taken up through rap, despite this discourse playing little or no role in mainstream hip hop culture. Rap also provides a means through which prisoners gain a sense of freedom and construct representations of reformed future selves. 


\section{Funding}

This work was supported by the Arts and Humanities Research Council [AH/M011275/3];

Economic and Social Research Council [ES/L003120/1]

Notes

i According to the dispersal model the most dangerous, escape-prone, or difficult to control prisoners are 'spread around a number of maximum security facilities so that their impact on the system is dissipated' (Wortley 2002)

\section{References}

Anderson, E. 1999. Code of the Street New York: Norton \& Co.

Bennett, A. 1999. 'Rappin' on the Tyne: White Hip Hop Culture in Northeast England' The Sociological Review Vol. 47, Issue 1, pp. 1-24.

Bennett, J. 2013. 'Race and Power: The Potential and Limitations of Prison-Based Democratic Therapeutic Communities' Race and Justice 3(2) 130-143.

Bramwell, R. 2015. UK Hip-Hop, Grime and the City New York and London: Routledge.

Bosworth, M. and Carrabine, E. 2001. 'Reassessing Resistance: Race, Gender and Sexuality in Prison' Punishment and Society Vol. 3 No. 4 pp. 501-15.

Chang, J. 2005. Can't Stop, Won't Stop London: Ebury Press.

Cummings, A. 2012. 'Thug's Life: Hip Hop's Curious Relationship with Criminal Justice' in L. Cheliotis (ed.) The Arts of Imprisonment Farnham: Ashgate.

Cusick, S. 2008. "“You are in a place that is out of the world...": Music in the Detention Camps of the "Global War on Terror"" Journal of the Society for American Music 2: 1.

Daveson, A. and Edwards, J. 2001. 'A descriptive study exploring the role of music therapy in prisons' The Arts in Psychotherapy 28 137-141.

Dedman, T. 2011. 'Agency in UK hip-hop and grime youth subcultures: peripherals and purists' Journal of Youth Studies, 14:5, 507-522.

Dehanas, D. 2013. 'Keepin' it Real: London Youth Hip Hop as an Authentic Performance of Belief’ Journal of Contemporary Religion, 28:2, 295-308.

DeNora, T. 1999 'Music as a technology of the self' Poetics 27: 31-56.

Dimitriadis, G. 2009. Performing Identity/Performing Culture New York: Peter Lang Publishing.

Earle, R. and Phillips, C. 2013. "'Muslim is the New Black": New Ethnicities and New Essentialisms in the Prison' Race and Justice 3: 114.

Genders, E. and Player, E. 1989. Race Relations in Prisons Oxford: Clarendon Press.

Gilroy, P. 1991. 'Sounds Authentic: Black Music, Ethnicity and the Challenge of a "Changing" Same' Black Music Research Journal 11:2. 
1993. The Black Atlantic London: Verso.

1994. "“After the Love Has Gone": bio-politics and etho-poetics in the black public sphere' Public Culture, 7.

Hall, S. 1992. 'New Ethnicities' in 'Race', culture and difference edited by J. Donald \& A. Rattansi London: Sage.

hooks, b. 1992. Black Looks Boston: South End Press.

Ilan, J. 2012. “The Industry's the New Road”: Crime, commodification and street cultural tropes in UK urban music', Crime, Media, Culture, 8(1), 39-55.

Jamison, D. 2006. 'The Relationship between African Self-Consiousness, Cultural Misorientation, Hypermasculinity, and Rap Music Preference' Journal of African American Studies 9:4, 45-60.

Joly D. 2007. 'Race Relations And Islam in the Prison Service' The International Journal of Human Rights, 11:3, 307-326.

Joly, D and Beckford, J. 2006. “"Race” Relations and Discrimination in Prison' Journal of Immigrant \& Refugee Studies, 4:2.

Kubrin, C. E., \& Nielson, E. 2014. 'Rap on trial.' Race and Justice, 4:3, 185-211.

Liebling, A. and Arnold, H. 2012. 'Social relationships between prisoners in a maximum security prison: Violence, faith, and the declining nature of trust' Journal of Criminal Justice Vol. 40, No. 5: $413-424$.

Liebling, A., Arnold, H., \& Straub, C. 2012. 'Staff-Prisoner Relationships at HMP Whitemoor: Twelve Years On’ London: National Offender Management Service.

Marcus, S. 2007. Music in Egypt. Oxford University Press.

Narey, M. 2001. 'Foreword', in HM Prison Service Annual Report and Accounts: April 2000March 2001, 6-7. London: HMSO.

NOMS. 2008. Race Review 2008: Implementing Race Equality in Prisons - Five Years On London: National Offender Management Service.

Pardue, D. 2004. "“Writing in the Margins": Brazilian Hip-Hop as an Educational Project'. Anthropology and Education Quarterly, 35:4, 411-432.

Perullo, A. 2005. 'Hooligans and Heroes: Youth Identity and Hip-Hop in Dar es Salaam, Tanzania' Africa Today 51:4.

Phillips, C. 2012. The Multicultural Prison Oxford: Oxford University Press.

Potter, R. 1995. Spectacular Vernaculars Albany: State University of New York Press.

Quinn, E. 2005. Nothing but a “G” Thing New York; Chichester: Columbia University Press.

Rose, T. 1994. Black Noise Hanover, N.H. : Wesleyan University Press.

Shiloah, A. 2001. Music in the world of Islam Wayne State University Press. 
Spalek, B. and El-Hassan, S. 2007. 'Muslim Converts in Prison' Howard Journal of Criminal Justice Vol 46 No 2.

Tuastad, L. and O'Grady, L. 2013. 'Music therapy inside and outside prison - A freedom practice?' Nordic Journal of Music Therapy, 22:3, 210-232.

Wortley, R. 2002. Situational prison control Cambridge University Press. 